\title{
An overview of the policy and legislative framework for the management of rangelands in Botswana and implications for sustainable development
}

\author{
K. Mulale \& W. L. Hambira \\ University of Botswana, Department of Environmental Science, Botswana
}

\begin{abstract}
The overall aim of the study is to investigate the extent to which the policy and legislative framework in Botswana facilitates or constrains sustainable communal rangelands management and utilization systems. Issues of sustainable management of communal rangelands are pertinent in Botswana since the majority of the people in Botswana live in rural areas and are particularly dependent on rangelands resources held in common for their livelihoods. The study undertook a content analysis of policy and legislative documents for the most relevant sectors and issues. The policy and legislative framework for the management of communal rangelands resources has far reaching implications for the sustainability of rural livelihoods in Botswana. The study findings show that despite their high dependence upon communal rangelands resources, rural communities have limited and insecure rights over these rangelands, hence their vulnerability. Findings also show that state policies and legislation tend to favour central regulation and privatization of communal rangelands resources.

Keywords: Botswana, Community Based Natural Resource Management, communal rangelands, policy and legislative framework, user rights.
\end{abstract}

\section{Introduction}

Local communities' ability to care for communal rangelands is affected by the socio-economic and political setting in which they live. Fernie and Pitkethly [1] have argued that, all resource problems are fundamentally institutional problems. Gupta [2] also observed that simply passing a law is not the equivalent of 
creating an effective institution. The policy and legislative framework can simultaneously be facilitative and obstructive to sustainable communal rangelands management depending upon the ability to create an effective institutional framework. Conflicting policy proposals for governing communal rangelands have been suggested and implemented in different parts of the world. At one end of the spectrum are policies favouring central regulation and privatization. At the other are policies that favour devolution and participation. In support of policies that favour central regulation, Terborgh [3] argues that local communities are unable to manage their resources, hence the need for state regulation and control. While Hardin's [4] hypothesis of the "Tragedy of the Commons" prescribes that communal rangelands ought to be privatized if effective management is to be achieved, studies by Ostrom [5]; Murphree [6]; Drinkwater [7]; Lawry [8]; Murombedzi [9,10] propose the communal proprietorship institutional arrangement as an alternative to the traditional central regulation and privatization of communal rangelands resources paradigm.

In Botswana, just like in other parts of Africa, issues of how best to manage communal rangelands are important. Communal rangelands management approaches proposed and implemented to date tend to favour privatization and central regulation. In instances where rangelands resource management decentralization programs have been adopted, such programs are preceded by centralization of rangelands resources and subsequent issuing of user rights as is the case with the Community Based Natural Resource Management Program (CBNRM). Taylor [11] criticised Botswana's CBNRM program as favouring government-led processes of decision making which has resulted in inadequate transfer of powers to local governments or user groups. Hence local governments or user groups lack authority to manage the resource (Taylor [11]).

The overall aim of the study is to investigate the extent to which the policy and legislative framework in Botswana facilitates or constrains sustainable communal rangelands management and utilisation systems. The study undertook a content analysis of policy and legislative documents for the most relevant sectors and issues. Findings show that state policies and legislation tend to favour central regulation and privatization of communal rangelands resources and in instances where CBNRM is implemented user groups or communities do not have tenure rights.

\section{Review of Communal Rangelands Resources Management and Utilization Policies and Legislation in Botswana}

A content analysis of the following policies and acts was made in view of sustainable communal rangeland management

\subsection{Tribal Land Act of 1968}

Tribal Land Act of 1968 transferred power over tribal land administration from the tribal chiefs to the Land Board, an institution accountable to the central government and not the community, though controlling community resources. 
Chiefs traditionally played a role in land allocation and management of communal rangelands resources (Zufferey [12]). Zufferey [12] observes that with the loss of control over resources, chieftainship was weakened as a traditional community decision making institution. The Tribal Land Act of 1968 aims at effective communal/tribal land administration by transferring the authority over the administration of land from the tribal chiefs to the Land Board. The Land Board regulates the use of tribal or communal land by granting land use rights. The act believes that state ownership and regulation of land resource use is key to sustainable land management and development.

\subsection{Agricultural Resources Conservation Act of 1974}

The Agricultural Resources Conservation Act of 1974 brought soils, water, and the flora and fauna of Botswana under the Agricultural Resources Board (ARB) of the Ministry of Agriculture. The Board has since relocated to the Ministry of Environment, Wildlife and Tourism. The main duty of the Board is to encourage proper conservation, use and improvement of agricultural resources. The Agricultural Resources Conservation Act of 1974 aims at achieving sustainable utilization and management of agricultural resources by bringing agricultural resources under ARB. ARB regulates the utilization of agricultural resources by individuals and communities by issuing harvest licenses. The act believes that state ownership and regulation of agricultural resource use is key to sustainable management and use of agricultural resources.

\subsection{The Wildlife Conservation Policy of 1986}

The Wildlife Conservation Policy of 1986 converted stretches of land that were formerly designated as "reserved" under the Tribal Grazing Land Policy of 1975 into wildlife management areas (WMAs). According to Botswana's National Development Plan 9 2003/04 to 2008/09 (MFDP, [13], WMAs were established by the Department of Wildlife and National Parks (DWNP) and Division of Land Use Planning to serve as migratory corridors for wildlife between the protected areas so as to allow movement that is essential for the survival of Botswana's wildlife in the arid environment. The WMAs were further subdivided by DWNP and the Division of Land Use Planning into Controlled Hunting Areas (CHAs), and these CHAs were subsequently earmarked for various kinds of management and utilization. All in all, the WMAs were subdivided into one hundred and sixty-three CHAs. The CHAs are today the major land units utilized for Community Based Natural Resource Management activities. Once CHAs are zoned by the Division of Land Use Planning and DWNP, villages within the geographic area are subsequently mobilized by the DWNP and other CBNRM facilitating NGOs into a Community Based Organization (Cassidy and Madzwamuse, [14]). The CBNRM CBO is entitled to a resource use lease from the Land Board and DWNP.

The Wildlife Conservation Policy of 1986 aims at sustainable utilization and management of wildlife resources by regulating the commercial and subsistence use of wildlife resources. DWNP regulates utilization of wildlife resources by 
awarding annual wildlife off-take quotas. The act believes that state ownership and regulation of wildlife resource use is essential for sustainable wildlife management and use.

\subsection{The Wildlife Conservation And National Parks Act of 1992}

The Wildlife Conservation and National Parks Act of 1992 legally recognises the establishment of National Parks, Game Reserves, Wildlife Management Areas and Community Hunting Areas. It brings all wildlife management units under the jurisdiction of the Department of Wildlife and National Parks. The Wildlife Conservation and National Parks Act of 1992 like the Wildlife Conservation Policy of 1986, aims at sustainable utilization and management of wildlife resources by among other things giving hunting licenses or permits to individuals and wildlife resource use leases to CBNRM CBOs. Like the Wildlife Conservation Policy of 1986, the act believes that state ownership and regulation of wildlife resource use is essential for sustainable wildlife management and use.

\subsection{Tribal Grazing Land Policy (TGLP) of 1975}

The Tribal Grazing Land Policy (TGLP) of 1975 was initiated in 1975 to allocate and regulate the tribal/communal grazing land. Under TGLP, approximately 335,000 ha of communal land was converted to leasehold ranches. The new owners of the ranches were given exclusive rights to not only the land, but also all the wildlife and plant resources within their ranches (White [15]). TGLP ranches were created on land perceived by the government as unoccupied. However, it was discovered through population surveys and adjudication meetings that much of the land newly designated as 'commercial' was in fact intensively used by people living in the communal areas and 'the planners' assumption that there were large areas of "empty" land [was] conclusively shown to be false' (White, [15]; also Peters [16). Hitchcock's [17] study on the 'Kgalagadi Cattle Posts', pointed out that the proposed TGLP areas were inhabited and extensively utilized, particularly by the San. Taylor [11] quotes a study conducted by the World Bank for the Ministry of Agriculture in which an estimated 28,000-31,000 people were displaced by the TGLP ranches.

The TGLP of 1975 aims at sustainable utilization and management of communal grazing land and increased economic output from the livestock sector by favouring private cattle ranch creation in communal rangelands. The policy believes that Private cattle ranch creation in communal rangelands is essential for the effective management of communal rangelands.

\subsection{National Policy on Agricultural Development (NPAD) of 1991}

According to the National Policy on Agricultural Development (NPAD) of 1991 farmers owning boreholes on communal land are allowed to fence $8 \mathrm{~km}$ by $8 \mathrm{~km}$ around their boreholes, gaining exclusive grazing rights in the fenced areas. It is important to note that there are few, if any, community boreholes in the communal grazing areas and that large cattle farmers own most of these 
boreholes (Mulale, [18]). NPAD is an expansion of TGLP. White [15] has argued that, the poor performance in TGLP ranches does not warrant such major changes in policy as envisaged by NPAD, for there is no justification in expanding private farm areas.

The NPAD of 1991 like the TGLP of 1975 also aims at sustainable utilisation and management of communal grazing land and increased economic output from the livestock sector by favouring private cattle ranch creation in communal rangelands. Like the TGLP of 1975 the policy believes that private cattle ranch creation in communal rangelands is essential for the effective management of communal rangelands.

\section{Discussion}

It is clear from the content analysis of Government of Botswana communal rangelands policies and legislation that the government is inclined towards centralization and privatization of communal rangelands resources under central government and private ownership respectively. The central government believes that it is best placed to effectively regulate the use of communal rangelands resources and that communal proprietorship results in communal rangelands degradation. This mindset is in line with Terborgh [3] belief that it is only the state institution that is best placed to regulate and control the use of communal rangelands resources. The Agricultural Resources Conservation Act of 1974, the Wildlife Conservation and National Parks Act of 1992, Wildlife Conservation Policy of 1986, and the Tribal Land Act of 1968 all aim at regulating the use of communal rangelands as a means for achieving desired outcomes.

Ostrom [19] indicates that central regulation and privatisation of natural resource use does not lead to improved natural resources management. The call for empowering resource users to become participants in the natural resource management decisions is presented as an alternative and gave rise to the idea of Community Based Natural Resources Management (CBNRM). CBNRM points to the need for a shift from classifying communities as resource users to considering communities as resource managers. Though the idea of CBNRM is embraced by the Government of Botswana, the actual process of devolution of natural resource management to local communities is problematic. There is disparity between rhetoric, policy and implementation. A major challenge to CBNRM is whether CBNRM can proceed without reversing the resource centralizing legislation of the past. According to Lynch [20], the challenge is to overcome legislative impediments to CBNRM and propose that there be recognition of private community-based rights on land tenure and the resources therein as a starting point for reversing the land tenure centralizing policies of the past. In Botswana, Arntzen et al. [21] observed that before the adoption of the CBNRM program, it was not clear who was managing and controlling wildlife resources outside wildlife protected areas. With the adoption of the Wildlife Conservation Policy of 1986 and the Wildlife Conservation and National Parks Act of 1992, the DWNP formally endorsed its authority over wildlife resources in areas outside protected wildlife areas. Taylor [11] also observed that CBNRM 
has served to extend the authority and control of the state into communal areas outside state protected areas. CBNRM in Botswana was preceded by state expropriation and centralization of communal rangelands resources and the participation of local resource users has been limited to usufruct without tenure rights.

The Tribal Grazing Land Policy (TGLP) of 1975 and the National Policy on Agricultural Development (NPAD) of 1991 view private cattle ranch creation in communal rangelands as an essential requirement for the effective management of communal rangelands and for increased agricultural output. This line of thinking is in accord with Hardin's [4] hypothesis on the tragedy of the commons. The communal rangelands privatization policies in Botswana are expropriatory in the sense that communal rangelands resources are taken away from communal use for private use with no compensation for displaced communal resource users. Arntzen [22] observed that rangelands in Botswana are often economically undervalued, because analyses fail to take into account their multiple uses, focus on a single sector (such as livestock) and are geared towards one market product (such as beef sale or slaughter). It is thus believed that proper economic valuation of communal rangelands can also contribute to sustainable communal rangeland utilisation and management

\section{Conclusion}

The centralization of communal rangelands management has undermined local institutions development and evolution. Even with the adoption of CBNRM, the Government of Botswana simply endorsed regulatory utilization measures to user groups without transferring management and tenure rights over communal rangelands resources. As is currently the practice in Botswana's CBNRM program, the central government expropriates local natural resources, centralizes them, and devises regulatory ways to be followed by local communities in utilizing local natural resources. Though rural communities depend on local natural resources for their livelihood, natural resource use decisions are taken beyond the locality with little input from the local communities, hence their vulnerability. There is need to invert this situation by placing resource management and ownership in the hands of resource users and embed them in an institutional framework of downwardly accountable local governments.

\section{References}

[1] Fernie, J., \& Pitkethly A., Resources: Environment and Policy. Harper and Row: London, 1985.

[2] Gupta, J., Water Law and Governance. International Human Dimensions Programme on Global Environmental Change: Bonn, 2004.

[3] Terborgh, J., Requiem for Nature. Island Press: Washington DC, 1999.

[4] Hardin, G., Tragedy of the Commons. Science 162, pp. 1243 - 1248, 1968.

[5] Ostrom, E., Governing the Commons: The Evolution of Institutions for Collective Action. Cambridge University Press: Cambridge. 1990. 
[6] Murphree, M., Congruent Objectives, Competing Interests and Strategic Compromise. Concept and Process in Zimbabwe's CAMPFIRE Programme. Paper Presented to the Conference on Representing Communities: Histories and Politics of Community Based Resource Management. Georgia, 1997.

[7] Drinkwater, M., The State and Agrarian Change in Zimbabwe's Communal areas. Macmillan Press: London, 1991.

[8] Lawry, S., Tenure Policy and Natural Resource Management in Sahelian West Africa. Land Tenure Centre, University of Wisconsin: Madison, 1989.

[9] Murombedzi, J., The Need for Appropriate Local Level, Common Property Resource Management in UZ, Harare, Zimbabwe. 1989.

[10] Murombedzi, J., The Need for Appropriate Local Level Common Property Resource Management Institutions in Communal Tenure Regimes. Centre for Applied Social Sciences Occasional Paper Series: University of Zimbabwe, 1990.

[11] Taylor, M., CBNRM and pastoral development in Botswana: Implications for San land rights. Paper presented at the conference on International Land Coalition. Rome, 2006.

[12] Zufferey, F., A Study of Local Institutions and Resource Management Inquiry in Eastern Central District - Botswana. Land Tenure Center. University of Wisconsin: Madison, 1986.

[13] Ministry of Finance and Development Planning (MFDP), National Development Plan 9: 2003/04-2008/09. Government Printer: Gaborone, 2003.

[14] Cassidy, L., \& Madzwamuse, M., (eds). Community Mobilisation in CBNRM in Botswana. Report of Workshop Proceedings. SNV/IUCN. Gaborone. Botswana. 1999

[15] White, R., Livestock Development and Pastoral Production on Communal Rangelands in Botswana. The Botswana Society: Gaborone, 1993.

[16] Peters, P., Dividing the Commons: Politics, Policy and Culture in Botswana. University Press of Virginia: Charlottesville and London, 1994.

[17] Hitchcock, R., Kalahari Cattle Posts. Ministry of Local Government and Lands: Gaborone, 1978.

[18] Mulale, K., The Challenges of Sustainable Beef Production in Botswana: Implications on Rangeland Management. 17th Symposium of the Farming Systems Association. Lake Buena Vista. Orlando, Florida, 2002.

[19] Ostrom, E., How Types of Goods and Property Rights Jointly Affect Collective Action. Journal of Theoretical Politics, 15(3), pp. 239 - 270, 2003.

[20] Lynch, O., Law, Pluralism and the Promotion of Sustainable Community Based Forest Management. Unasylva, 194(49), pp. 52-56, 1998.

[21] Arntzen, J., Molokomme, K., Tshosa, O., Moleele, N., Mazambani, D., \& Terry, B., Final report of a study carried out for the National CBNRM 
580 Sustainable Development and Planning III

Forum on the review of Community Based Natural Resource Management in Botswana, Centre for Applied Research: Gaborone, Botswana, 2003.

[22] Arntzen, J., Economic Valuation of communal rangelands in Botswana: A case study. CREED working paper series No.17. International Institute for Environment and Development: London and Vrije Univesiteit, Amsterdam, 1998. 